\title{
Impact of different environmental conditions on the aggregation of biogenic U(IV) nanoparticles synthesized by Desulfovibrio alaskensis $\mathrm{G} 20$
}

\author{
Authors: S. Sevinç Şengör, Gursharan Singh, Alice \\ Dohnalkova, Nicolas Spycher, Timothy R. Ginn, \\ Brent M. Peyton, \& Rajesh K. Sani
}

The final publication is available at Springer via http://dx.doi.org/10.1007/s10534-016-9969-6.

Şengör SS, Singh G, Dohnalkova A, Spycher N, Ginn TR, Peyton BM, Sani RK, "Impact of different environmental conditions on the aggregation of biogenic $U(\mathrm{IV})$ nanoparticles synthesized by Desulfovibrio alaskensis G20," BioMetals. 2016 December;29(6):965-980. DOI: 10.1007/ s10534-016-9969-6. 


\section{Impact of different environmental conditions on the aggregation of biogenic U(IV) nanoparticles synthesized by Desulfovibrio alaskensis G20}

S. Sevinc, S, engör, Gursharan Singh, Alice Dohnalkova, Nicolas Spycher, Timothy R. Ginn, Brent M. Peyton, \& Rajesh K. Sani

This study investigates the impact of specific environmental conditions on the formation of colloidal U(IV) nanoparticles by the sulfate reduc-ing bacteria (SRB, Desulfovibrio alaskensis G20). The reduction of soluble U(VI) to less soluble U(IV) was quantitatively investigated under growth and non-growth conditions in bicarbonate or 1,4-piperazinedi-ethanesulfonic acid (PIPES) buffered environments. The results showed that under non-growth conditions, the majority of the reduced $U$ nanoparticles aggre-gated and precipitated out of solution. High resolution transmission electron microscopy revealed that only a very small fraction of cells had reduced $U$ precipitates in the periplasmic spaces in the presence of PIPES buffer, whereas in the presence of bicarbonate buffer, reduced $U$ was also observed in the cytoplasm with greater aggregation of biogenic U(IV) particles at higher initial U(VI) concentrations. The same exper-iments were repeated under growth conditions using two different electron donors (lactate and pyruvate) and three electron acceptors (sulfate, fumarate, and thiosulfate). In contrast to the

results of the non-growth experiments, even after $0.2 \mathrm{~lm}$ filtration, the majority of biogenic U(IV) remained in the aqueous phase resulting in potentially mobile biogenic U(IV) nanoparticles. Size fractionation results showed that U(IV) aggregates were between 18 and $200 \mathrm{~nm}$ in diameter, and thus could be very mobile. The findings of this study are helpful to assess the

size and potential mobility of reduced $U$ nanoparticles under different environmental conditions, and would provide insights on their potential impact affecting U(VI) bioremediation efforts at subsurface contaminated sites. 
Keywords Biogenic uranium - Mobile uraninite Nanoparticles $\cdot$ Sulfate reducing bacteria .

Uranium aggregates

\section{Introduction}

Biogenic U(IV) is the most desirable product of in situ microbial reduction of subsurface U(VI) because it has lower solubility compared to most other U species. At least three different types of biogenic U(IV) have been observed: crystalline uraninite, nanoparticulate uraninite, and mononuclear U(IV) (Maleke et al. 2015; Zhou et al. 2014a, b; Singh et al. 2014; Boyanov et al. 2011; Fletcher et al. 2010; Bernier-Latmani et al. 2010). These reduced forms of $\mathrm{U}$ are prone to re-oxidation, raising questions regarding long-term $\mathrm{U}$ remediation and site stewardship (Singh et al. 2014; Spycher et al. 2011; Moon et al. 2009; Beyenal et al. 2004). Following the microbial reduction of U(VI) to U(IV), the second step in biogenic U(IV) formation entails the aggregation of the precipitated mineral. It is generally believed that uraninite aggregates near the site of U(VI) reduction (Sani et al. 2008; Bargar et al. 2008; Fredrickson et al. 2002). It has been suggested that complexed U(IV) or nanoparticulate uraninite can diffuse out of the periplasm following reduction (Marshall et al. 2006).

Although microorganisms capable of reducing U(VI) are widespread in the natural subsurface, their in situ activities are constrained by competition for electron donors, electron acceptors, and other site specific factors (Suzuki and Suko 2006). An attractive approach for the reductive precipitation of U(VI) in contaminated environments typically involves the utilization of electron donors to establish anoxic conditions in an aquifer, which is followed by microbial reduction of electron acceptors such as $\mathrm{NO}_{3}{ }^{-}, \mathrm{U}(\mathrm{VI}), \mathrm{Fe}(\mathrm{III})$, and $\mathrm{SO}_{4}{ }^{2-}$. The presence of an electron donor is an important prerequisite for the bioreduction of U(VI) (Wall and Krumholz 2006; Tapia-Rodriguez et al. 2010). A summary of various electron donors used for the effective bioreduction of $\mathrm{U}(\mathrm{VI})$ is given in Table 1. Despite the use of various electron donors for U(VI) bioreduction, comparative studies investigating the most efficient carbon source for the immobilization of $U$ are scarce.

The oxidation of an electron donor is coupled to the reduction of an electron acceptor. In the subsurface sediments, a range of diverse electron acceptors, e.g., $\mathrm{NO}_{3}{ }^{-}, \mathrm{Mn}(\mathrm{IV}), \mathrm{Fe}(\mathrm{III})$, and $\mathrm{SO}_{4}{ }^{2-}$ can be used by the microorganisms and the sequence of use depends on their availability, redox potential (Lovley 1991; Nealson and Saffarini 1994), as well as other governing ecological and physiological factors (Bethke et al. 2011). The presence of these competing electron acceptors in field sites can constrain ongoing bioremediation efforts, as the preferential use of alternative electron acceptors by microorganisms may delay or even completely inhibit U(VI) reduction (Junier et al. 2010). Various studies have evaluated the impact of competing electron acceptors on U(VI) bioreduction and observed highly variable results, depending on the microbial community and the specific microorganism tested, as well as the speciation of U(VI) (Istok et al. 2004; Elias et al. 2004; Anderson et al. 2003; Pietzsch and Babel 2003; Finneran et al. 2002; Spear et al. 1999).

The properties of biogenic U(IV) nanoparticles, particularly solubility and dissolution kinetics, are crucial to the viability of microbial bioremediation strategies that seek to mitigate subsurface U(VI) contamination. The stability and fate of the biologically produced U(IV) particles depends on their size, structure, and composition. Detailed characterization of the structure and nanoparticulate nature of biogenic U(IV) produced by Shewanella oneidensis strain MR-1 was reported by Schofield et al. (2008). They observed fresh nanoparticles with an interior average diameter of $1.3 \mathrm{~nm}$ and an outer region of thickness ca $\sim 0.6 \mathrm{~nm}$. Desulfosporosinius sp. has been documented to form nanoparticulate uraninite with less than $2 \mathrm{~nm}$ diameter (Suzuki et al. 2002). (Sharpe et al. 2009) observed the average sizes of biogenic uraninite precipitates produced by Shewanella sp. HRCR-2, Anaeromyxobacter dehalogenans, Geobacter sulfurreducens, and Desulfovibrio vulgaris, as 1.96, 1.91, 2, and $1.83 \mathrm{~nm}$, respectively. Senko et al. (2007) reported the size of uraninite nanoparticles produced by Shewanella putrefaciens CN32 to be from 0.9 to $3 \mathrm{~nm}$. They observed that the U(IV) particles that were formed at relatively slow rates of U(VI) bioreduction were more highly aggregated, and were oxidized at a slower rate, than those formed at relatively fast rates of $\mathrm{U}(\mathrm{VI})$ bioreduction. However, Burgos et al. (2008) observed no discernible effect of U(VI) bioreduction rate by Shewanella oneidensis MR-1 on uraninite particle size or oxidation rate, suggesting that various inter-related factors including cell cultivation methods, cell metabolic states, molecular-scale 
Table 1 Summary of various electron donors and electron acceptors used for the effective bioremediation of U(VI)

\begin{tabular}{|c|c|c|}
\hline Electron donor & Electron acceptor & Reference \\
\hline $\begin{array}{l}\text { Acetate, lactate, pyruvate and } \\
\text { ethanol }\end{array}$ & $\begin{array}{l}\mathrm{Fe}(\mathrm{III}), \mathrm{Mn}(\mathrm{IV}) \text {, anthraquinone-2,6-disulfonate, } \\
\text { malate, and fumarate }\end{array}$ & Shelobolina et al. (2008) \\
\hline Acetate & $\mathrm{NO}_{3}{ }^{-}$ & Finneran et al. (2002) \\
\hline Acetate & $\mathrm{Fe}(\mathrm{III})$ & Holmes et al. (2002) \\
\hline Acetate & $\mathrm{Fe}(\mathrm{III}), \mathrm{SO}_{4}^{-2}$ & $\begin{array}{l}\text { Anderson et al. (2003), Vrionis et al. (2005), } \\
\text { Williams et al. (2011) }\end{array}$ \\
\hline Acetate & $\mathrm{NO}_{3}^{-}, \mathrm{Fe}(\mathrm{III}), \mathrm{SO}_{4}^{-2}$ & Nevin et al. (2003) \\
\hline Acetate, ethanol & $\mathrm{NO}_{3}^{-}, \mathrm{Fe}(\mathrm{III}), \mathrm{SO}_{4}^{-2}$ & Converse et al. (2013) \\
\hline Acetate & $\mathrm{Fe}(\mathrm{III})$, fumarate & Esteve-Núnez et al. (2004) \\
\hline Acetate, $\mathrm{H}_{2}$ & $\mathrm{Fe}(\mathrm{III}), \mathrm{Mn}(\mathrm{IV})$ & Marshall et al. (2009) \\
\hline Acetate, ethanol & $\mathrm{SO}_{4}^{-2}$ & Luo et al. (2007) \\
\hline Acetate, $\mathrm{H}_{2}$ & $\begin{array}{l}\text { Nitrate, } \mathrm{Fe}(\mathrm{III}), 2 \text {-chlorophenol (2-CP), and } \\
\text { fumarate }\end{array}$ & Wu et al. (2006) \\
\hline Acetate, ethanol, glucose & $\mathrm{NO}_{3}^{-}$ & Istok et al. (2004) \\
\hline Pyruvate & Only U(VI) & $\begin{array}{l}\text { Fletcher et al. (2010) and Bernier-Latmani } \\
\text { et al. (2010) }\end{array}$ \\
\hline Ethanol & $\mathrm{O}_{2}, \mathrm{NO}_{3}{ }^{-}, \mathrm{Fe}(\mathrm{III})$, sulfate & Wu et al. (2007) \\
\hline Pyruvate & $\mathrm{NO}_{3}{ }^{-}, \mathrm{SO}_{4}{ }^{-2}$, soluble ferric iron & Junier et al. (2010) \\
\hline $\begin{array}{l}\text { Formate, butyrate butanol, } \\
\text { benzoate and toluene }\end{array}$ & Soluble ferric iron, elemental sulfur, fumarate & Prakash et al. (2010) \\
\hline Lactate, $\mathrm{H}_{2}$ & $\mathrm{Fe}(\mathrm{III}), \mathrm{Co}(\mathrm{III}), \mathrm{U}(\mathrm{VI}), \mathrm{Cr}(\mathrm{VI})$, and $\mathrm{Tc}(\mathrm{VII}) \mathrm{i}$ & Liu et al. (2002) \\
\hline
\end{tabular}

mechanisms of $\mathrm{U}(\mathrm{VI})$ reduction, $\mathrm{U}(\mathrm{IV})$ nucleation site, cellular location of uraninite precipitates, and secondary effects of oriented aggregation could control particle size. Despite the evidence for the involvement of phylogenetically diverse bacteria in environmental $\mathrm{U}(\mathrm{VI})$ reduction, there remains a lack of detailed knowledge on the impact of the buffers present in the medium, and the impact of different environmental conditions on the bioreduction of U(VI) by subsurface microorganisms and the aggregation of biogenic U(IV) nanoparticles.

The present study is the first attempt to explore the impact of various physiological conditions of sulfate reducing bacteria (SRB, which are commonly found in U-contaminated subsurface sites) on the formation of colloidal U(IV) nanoparticles including (i) determining the impact of specific $\mathrm{pH}$ buffers on the aggregation of biogenic U(IV) nanoparticles, (ii) examining the effect of various electron donors and acceptors on the reduction of U(VI) and aggregation of biogenic U(IV) nanoparticles, and (iii) characterizing the size fractionation of the resulting reduced U(IV) nanoparticles. We used D. alaskensis $\mathrm{G} 20$ as a model organism because Desulfovibrio species are present in many subsurface sites and can play an important role in metal cycling (Stylo et al. 2015; Zhou et al. 2014a; Anderson et al. 2003). D. alaskensis G20 can grow using lactate and pyruvate as electron donors; and sulfate, thiosulfate, and fumarate as electron acceptors. Although lactate, pyruvate and sulfate are the electron donors and acceptors that are prevalent in most natural and engineered subsurface environments, thiosulfate and fumarate were also tested as alternative electron acceptors in this study to investigate their effect on biogenic U(IV) nanoparticle aggregation. The effect of the two buffers, bicarbonate and PIPES, and the behavior of SRB under growth versus non-growth conditions on the aggregation of biogenic U(IV) nanoparticles was also examined.

\section{Materials and methods}

Microorganism and culture conditions

Desulfovibrio alaskensis G20 (formerly known as Desulfovibrio desulfuricans G20-Hauser et al. 2011; hereafter simply referred to as G20 throughout the manuscript) used in the present study was a gift of J. 
Wall, University of Missouri-Columbia (Columbia, MO, USA). G20 was maintained in a modified lactate$\mathrm{C}$ medium called metal toxicity medium (MTM, Sani et al. 2001) containing bicarbonate buffer. The $\mathrm{pH}$ of the medium was 7 . The medium components were analytical grade purchased from Fisher Scientific (Pittsburgh, PA) or Difco Chemical Co. (Detroit, MI). 1,4-piperazinediethane sulfonic acid disodium salt monohydrate (PIPES) and sodium sulfate were obtained from Aldrich Chemical Co. (Milwaukee, WI). Uranium was purchased as $\mathrm{UO}_{2} \mathrm{Cl}_{2} \cdot 3 \mathrm{H}_{2} \mathrm{O}$ from Bodman Industries (Aston, PA). All glassware were washed with $2 \mathrm{~N} \mathrm{HNO}_{3}$.

G20 was grown in serum bottles containing MTM under anaerobic conditions. Serum bottles buffered with bicarbonate were capped with butyl-rubber septa, crimped with aluminum seals, purged, and pressurized with a mixture of $\mathrm{N}_{2}(80 \%)$ and $\mathrm{CO}_{2}(20 \%)$ at $68.9 \mathrm{kPa}(10 \mathrm{psi})$ above atmospheric pressure. While the serum bottles were buffered with PIPES, they were pressurized with $\mathrm{N}_{2}(100 \%)$. The $\mathrm{N}_{2}$ as well as gas mixtures were filtered through $0.2 \mu \mathrm{m}$ syringe filters (Gelman Acrodisc, San Diego, CA, USA). After inoculation, the serum bottles were incubated at $25{ }^{\circ} \mathrm{C}$ on a rotary shaker at $125 \mathrm{rpm}$.

\section{Batch experiments}

\section{Non-growth conditions}

To examine U(VI) reduction in batch cultures, experiments were carried out with washed cells suspended in bicarbonate or PIPES buffer each at $30 \mathrm{mM}$ and $\mathrm{pH}$ 7. Bicarbonate concentration $(30 \mathrm{mM})$ was used on the basis of other published results (e.g., Gorby and Lovley 1992, Fredrickson et al. 2002). G20 grown for 4 days were centrifuged under anaerobic conditions at $10,000 \times g$ for $10 \mathrm{~min}$. The supernatant was discarded and the cell pellets were suspended in the anoxic buffers with all transfers occurring in an anaerobic glove box. This process was performed three times and the cells were then re-suspended under non-growth conditions (defined here as the absence of nitrogen, phosphorous, vitamins, and other micronutrients) in bicarbonate or PIPES buffer (30 mM, pH 7) and used for U(VI) reduction. Aliquots of washed-cell suspension prepared under anaerobic conditions were added to anaerobic autoclaved bicarbonate or PIPES buffer in $25-\mathrm{mL}$ serum bottles to achieve an absorbance of
0.5 at $660 \mathrm{~nm}$ (note that 1 optical density was equal to $217.5 \mathrm{mg} / \mathrm{L}$ cell protein for G20 [unpublished results]). Serum bottles were amended with an excess of the electron donor, lactate, to a concentration of $10 \mathrm{mM}$ from a $1 \mathrm{M}$ stock solution. A filtered $(0.2 \mu \mathrm{m})$ anaerobic stock solution of $\mathrm{UO}_{2} \mathrm{Cl}_{2} \cdot 3 \mathrm{H}_{2} \mathrm{O}$ was aseptically added to the serum bottles to attain U(VI) concentration of 150 or $900 \mu \mathrm{m}$, which was the only electron acceptor. $150 \mu \mathrm{m}$ U(VI) concentration was chosen based on our prior studies (Sani et al. 2004) and $900 \mu \mathrm{m}$ was used to observe higher aggregation of U(IV) precipitates and matched concentrations used by Lovley and Phillips (1992). In addition to cell- and lactate-free controls, heat-killed cell controls were also included. The total volume of inoculated reaction mixture in each serum bottle was $10 \mathrm{~mL}$. Anoxic conditions were obtained by bubbling the solutions containing bicarbonate buffer, stock U(VI) solution, and lactate for $1 \mathrm{~h}$ with $\mathrm{N}_{2}: \mathrm{CO}_{2} \quad(80: 20)$ in the anaerobic glove box while serum bottles containing PIPES buffer were purged by $\mathrm{N}_{2}(100 \%)$. All these gases were filtered through $0.2 \mu \mathrm{m}$ syringe filters. All cultures were incubated at room temperature $\left(25^{\circ} \mathrm{C}\right)$ and shaken at $125 \mathrm{rpm}$. Samples were taken using disposable sterile syringes, which were purged with $\mathrm{N}_{2}$ to avoid introducing $\mathrm{O}_{2}$ into the serum bottles, and analyzed for uranium concentrations as described below. Each treatment was conducted in triplicate, with the initial sample taken anaerobically within 5 min after inoculation. Each batch experiment was repeated twice.

\section{Growth conditions}

$\mathrm{U}(\mathrm{VI})$ reduction experiments were carried out under growth conditions as well. Volumes of $100 \mathrm{ml}$ of MTM with $30 \mathrm{mM}$ bicarbonate buffer $(\mathrm{pH} \mathrm{7})$ were autoclaved in 150-ml serum bottles. In addition to sulfate, thiosulfate, or fumarate as electron acceptor, a filtered $(0.2 \mu \mathrm{m})$ anaerobic stock solution of $\mathrm{UO}_{2} \mathrm{Cl}_{2} \cdot 3 \mathrm{H}_{2} \mathrm{O}$ was aseptically supplemented to the serum bottles to attain a U(VI) concentration of $150 \mu \mathrm{m}$. The serum bottles containing PIPES or bicarbonate buffer were then sparged with $\mathrm{O}_{2}$-free ultra-pure $\mathrm{N}_{2}$ or $\mathrm{N}_{2}: \mathrm{CO}_{2}$ (80:20), respectively for $30 \mathrm{~min}$, sealed with butyl rubber septa, capped and crimped with aluminum seals. The serum bottles were pressurized at $68.9 \mathrm{kPa}$ above atmospheric pressure. These uninoculated serum bottles were shaken at $25^{\circ} \mathrm{C}$ on an orbital 
shaker (Lab-Line Instruments Inc., Melrose Park, IL, USA) at $125 \mathrm{rpm}$ for $6 \mathrm{~h}$, and samples were withdrawn aseptically to measure initial U(VI) concentrations. Thereafter, washed cells of G20 grown in MTM containing bicarbonate buffer were injected into all serum bottles to provide a final concentration of $3 \mathrm{mg} /$ L cell protein. Cells for inoculation were prepared after removing hydrogen sulfide initially present in a 4 day old active culture by flushing with ultra-pure nitrogen for $1 \mathrm{~h}$, and washed twice with bicarbonate buffer under anaerobic conditions as described previously (Sani et al. 2008). With each set of experiments, heat killed G20 (autoclaved at $121{ }^{\circ} \mathrm{C}$ for $15 \mathrm{~min}$ ), and $\mathrm{U}(\mathrm{VI})$-free controls were also used. After inoculation, serum bottles were again incubated at $25^{\circ} \mathrm{C}$ and $125 \mathrm{rpm}$. Periodically, $0.5-\mathrm{ml}$ samples were aseptically removed by a syringe and needle and analyzed for $\mathrm{U}(\mathrm{VI})$ concentrations.

\section{Effects of different electron donors and acceptors on biogenic $U(I V)$ aggregation}

$\mathrm{U}(\mathrm{VI})$ reduction experiments were performed in the MTM buffered by sodium bicarbonate $(30 \mathrm{mM}, \mathrm{pH}$ 7) containing different electron donors and acceptors. Initially six electron acceptors including sulfate, thiosulfate, sulfur, nitrate, nitrite, and fumarate were evaluated. With lactate as the electron donor, G20 showed very poor growth with sulfur, nitrate, or nitrite as electron acceptor. Therefore, an electron donor (lactate or pyruvate) and an electron acceptor (thiosulfate, fumarate, or sulfate) were selected for further studies. Each serum bottle with different electron donor (each at $30 \mathrm{mM}$ ) and acceptors (each at $20 \mathrm{mM}$ ) was inoculated with G20 cells to provide a final concentration of $3 \mathrm{mg} / \mathrm{L}$ cell protein. All bottles were incubated on a shaker $(125 \mathrm{rpm})$ at $25^{\circ} \mathrm{C}$. U(VI) reduction in each culture was measured for 8 days as described below.

\section{Analytical methods}

Microbial reduction of U(VI) was evaluated by monitoring the decrease in $\mathrm{U}(\mathrm{VI})$ concentration over time in filtered solutions. For determining the decrease of aqueous $\mathrm{U}(\mathrm{VI})$, samples $(0.2 \mathrm{~mL})$ were withdrawn by syringe and needle, and measured immediately after filtration (Gelman Acrodisc; pore diameter, $0.2 \mu \mathrm{m}$ ). This decrease in the measured U(VI) concentrations is referred to as "filtered reduced U" throughout the paper. Samples were diluted 1000-times with nanopure water to remove matrix effects, and then $1 \mathrm{~mL}$ of the sample was mixed with $1.5 \mathrm{~mL}$ of a complexing agent, Uraplex. Samples were analyzed with a kinetic phosphorescence analyzer (KPA-11, Chemcheck Instruments, Inc., USA), which uses a pulsed nitrogen dye laser to measure $\mathrm{U}(\mathrm{VI})$ concentrations in solution. Calibrations were performed using uranyl chloride solutions from 0 to $0.16 \mu \mathrm{m}$, yielding a $\mathrm{U}(\mathrm{VI})$ detection limit of $0.04 \mu \mathrm{m}$ with the precision of $\pm 5 \%$.

In addition to measurements of soluble U(VI), precipitation of $\mathrm{U}(\mathrm{IV})$ by bacterial reduction was evaluated by measuring total dissolved $U\{\mathrm{U}(\mathrm{VI})$ and $\mathrm{U}(\mathrm{IV})\}$ in the filtrate $(0.2 \mu \mathrm{m})$ samples. To oxidize $\mathrm{U}(\mathrm{IV})$ to $\mathrm{U}(\mathrm{VI})$, filtered samples $(0.1 \mathrm{~mL})$ were exposed to air for $1 \mathrm{~h}$, and $0.3 \mathrm{~mL}$ concentrated $\mathrm{HNO}_{3}$ was added (Lovley and Phillips 1992; Ganesh et al. 1997). The samples were vortexed and left for $1 \mathrm{~h}$ and diluted 100-times in nanopure water. After complete oxidation of reduced $\mathrm{U}$, the samples were further diluted 10-times in nanopure water and U(VI) was measured using the KPA-11 analyzer described above. Thus, these measurements corresponded to the total $\mathrm{U}$ \{i.e., $\mathrm{U}(\mathrm{VI})$ and oxidized $\mathrm{U}(\mathrm{IV})$ \}, which is referred to as "filtered oxidized U(VI)" throughout the paper. The amount of the biogenic U(IV) nanoparticles that were able to pass through the $0.2 \mu \mathrm{m}$ filter (referred to as mobile U(IV) in the text) was calculated by the difference between the filtered oxidized $\mathrm{U}(\mathrm{VI})$ and $\mathrm{U}(\mathrm{VI})$ concentrations for each of the conditions tested. The results of two different electron donors (lactate or pyruvate), three electron acceptors (sulfate, thiosulfate, or fumarate), two $\mathrm{pH}$ buffers (bicarbonate and PIPES), and two initial $\mathrm{U}(\mathrm{VI})$ concentrations $(150$ and $900 \mu \mathrm{M})$ on the effectiveness of $\mathrm{U}(\mathrm{VI})$ bioreduction is presented. Table 2 shows the summary of the experimental conditions considered in this study. The biogenic reduced $U$ which passed through 30 (pore size of $18 \mathrm{~nm}$ ), 10 (pore size of $6 \mathrm{~nm}$ ) or $3 \mathrm{kD}$ (pore size of $1.8 \mathrm{~nm}$ ) cut-off membrane filters was also measured.

\section{Transmission electron microscopy (TEM)}

Due to the $\mathrm{O}_{2}$-sensitive nature of the samples, the entire embedding procedure was conducted in an anaerobic glove box (Ar: $\mathrm{H}_{2}, 95: 5$; Coy Laboratory Products, Grass Lake, MI, USA) as described previously (Sani et al. 2008). The precipitates, resulting 
from batch experiments of G20 with 150 or $900 \mu \mathrm{m}$ U(VI) containing PIPES or bicarbonate buffer, were washed in anoxic deionized water, and fixed in $2.5 \%$ glutaraldehyde. This was followed by gradual dehydration in an ethanol series and infiltration with LR White embedding resin (Sigma, St. Louis, Mo, USA). Samples embedded in solid resin blocks were sectioned to $60-70 \mathrm{~nm}$ on a microtome (Leica Ultracut UCT; Leica Microsystems, Bannockburn, IL, USA), and sections were mounted on 200 mesh copper grids coated with formvar support film sputtered with carbon. Sections were examined using a JEOL 2010 high resolution transmission electron microscope (HR-TEM) equipped with a $\mathrm{LaB}_{6}$ filament operating at $200 \mathrm{kV}$ with resolution of $0.19 \mathrm{~nm}$ (JEOL USA, Peabody, MA, USA).

\section{Results and discussion}

In this study, the reduction of soluble U(VI) (150 and $900 \mu \mathrm{m})$ to $\mathrm{U}(\mathrm{IV})$ was quantitatively investigated in growth (liquid culture with MTM) and non-growth conditions using Desulfovibrio alaskensis-G20 in bicarbonate or PIPES buffered media. Size fractionation of the biogenic $\mathrm{UO}_{2}$ nanoparticle precipitates formed by G20 under growth conditions in the presence of bicarbonate buffer $(30 \mathrm{mM}$ and $\mathrm{pH} 7)$ is also discussed. The results presented here are useful to assess the size and potential mobility of non-aggregated reduced $U$ nanoparticles in the aqueous phase, and would provide insights on these nanoparticles affecting U(VI) bioremediation efforts at subsurface contaminated sites.

Evaluation of biogenic U(IV) nanoparticles produced in PIPES or bicarbonate buffer under non-growth conditions

The effects of bicarbonate or PIPES buffer (each at $30 \mathrm{mM}$ and $\mathrm{pH}$ 7) under non-growth conditions by G20 cells are shown in Figs. 1(a) and 1(b) for the initial 150 or $900 \mu \mathrm{M} \mathrm{U}(\mathrm{VI})$ concentrations, respectively. Lactate $(10 \mathrm{mM})$ was added as the electron donor and source of energy for keeping the cells metabolically active, but without $\mathrm{N}$ or $\mathrm{P}$, no further division or growth of cells was observed. The results show that G20 cells reduced the $\mathrm{U}(150$ and $900 \mu \mathrm{M})$ successfully within the first $4 \mathrm{~h}$, with greater than $93 \% \mathrm{U}(\mathrm{VI})$ reduction in either PIPES or bicarbonate buffer. On the other hand, with $900 \mu \mathrm{M}$ initial U(VI), $75 \% \mathrm{U}(\mathrm{VI})$ reduction was observed in the presence of bicarbonate buffer (Fig. 1c), while PIPES showed $95 \% \mathrm{U}(\mathrm{VI})$ reduction. Under these non-growth reducing conditions, $\mathrm{U}$ turned into black reduced $\mathrm{U}$ precipitates from its soluble U(VI) form. Sani et al. (2006) showed that with $100 \mu \mathrm{M}$ initial U(VI) concentration, G20 cells removed 95 and $50 \%$ of $\mathrm{U}(\mathrm{VI})$ from the solutions containing bicarbonate and PIPES buffers, respectively. The lower U(VI) removal in the presence of PIPES buffer was attributed to the lower solubility of U(VI) in PIPES buffer compared to the bicarbonate buffer. However, the addition of

Table 2 Summary showing the different environmental conditions used in this study

\begin{tabular}{|c|c|c|c|c|c|}
\hline Environmental conditions & Electron donor & Electron acceptor & Buffer & $\mathrm{pH}$ & $\begin{array}{l}\text { Initial U(VI) } \\
(\mu \mathrm{M})\end{array}$ \\
\hline \multirow[t]{6}{*}{ Growth } & Lactate & Sulfate & Bicarbonate & 7 & 150 \\
\hline & Lactate & Thiosulfate & Bicarbonate & 7 & 150 \\
\hline & Lactate & Fumarate & Bicarbonate & 7 & 150 \\
\hline & Pyruvate & Sulfate & Bicarbonate & 7 & 150 \\
\hline & Pyruvate & Thiosulfate & Bicarbonate & 7 & 150 \\
\hline & Pyruvate & Fumarate & Bicarbonate & 7 & 150 \\
\hline \multirow[t]{4}{*}{ Non-growth } & Lactate & $\mathrm{U}(\mathrm{VI})$ & Bicarbonate & 7 & 150 \\
\hline & Lactate & $\mathrm{U}(\mathrm{VI})$ & Bicarbonate & 7 & 900 \\
\hline & Lactate & $\mathrm{U}(\mathrm{VI})$ & PIPES & 7 & 150 \\
\hline & Lactate & $\mathrm{U}(\mathrm{VI})$ & PIPES & 7 & 900 \\
\hline
\end{tabular}


$1 \mathrm{mM}$ lactate to the PIPES buffer solution increased the U(VI) solubility (Sani et al. 2006). The higher $\mathrm{U}(\mathrm{VI})$ reduction in the presence of PIPES buffer observed in this study may be attributed to the higher solubility of $\mathrm{U}(\mathrm{VI})$ due to the higher lactate $(10 \mathrm{mM})$ concentration, resulting in the formation of uranyl lactate complexes such as $\mathrm{UO}_{2}$ (lactate) $^{+}$(e.g. Sani et al. 2006). Although the uranyl hydroxo complexes were the most dominant aqueous U(VI) species in the presence of PIPES buffer (as explained below), the higher concentrations of uranyl lactate complexes at $10 \mathrm{mM}$ lactate concentration (compared to $1 \mathrm{mM}$ lactate) may still have increased the U(VI) solubility resulting in higher $\mathrm{U}(\mathrm{VI})$ reduction.

The results in Fig. 1 show that at both U(VI) concentrations tested, the majority of the reduced $U$

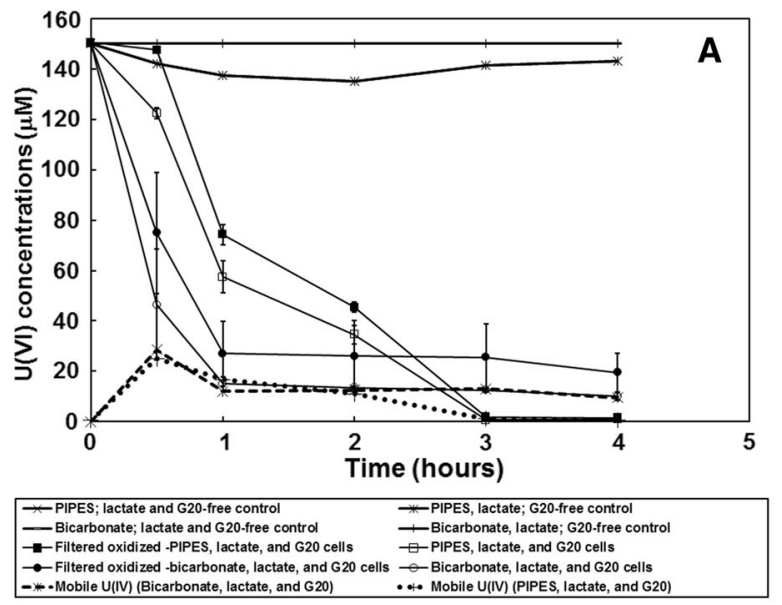

nanoparticles did not pass through the $0.2 \mu \mathrm{M}$ filter. This amount of $U$ nanoparticles, which did not aggregate, was denoted as mobile U(IV). This can be seen by the mobile U(IV) concentration trends that were able to pass through the $0.2 \mu \mathrm{m}$ filter (dashed lines in Fig. 1a, b) calculated by the difference between the filtered U(VI) and filter oxidized U(VI) concentrations which corresponded to only $0-8 \%$ bioreduced $U$ existing in mobile phase (Fig. 1c). The results therefore showed that less than $9 \%$ of the $\mathrm{U}(\mathrm{IV})$ was in the mobile phase, for the non-growth conditions for $\mathrm{G} 20$ cells reducing 150 or $900 \mu \mathrm{M}$ $\mathrm{U}(\mathrm{VI})$ with using either PIPES or bicarbonate buffer. Therefore, the majority of the U(IV) aggregated and precipitated out of the solution under these nongrowth conditions. It should be noted that although the

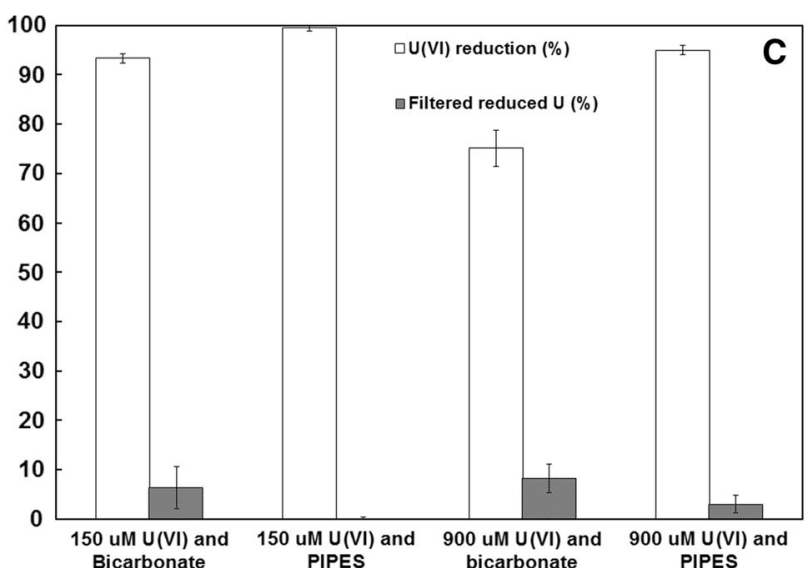

Fig. 1 The effects of bicarbonate or PIPES buffer (each at $30 \mathrm{mM}$ and $\mathrm{pH} 7$ ) on a 150 , b $900 \mu \mathrm{m} \mathrm{U}(\mathrm{VI})$ reduction under non-growth conditions by $D$. desulfuricans G20. c Comparative distribution of \% $\mathrm{U}(\mathrm{VI})$ reduction and \% filtered reduced $\mathrm{U}$

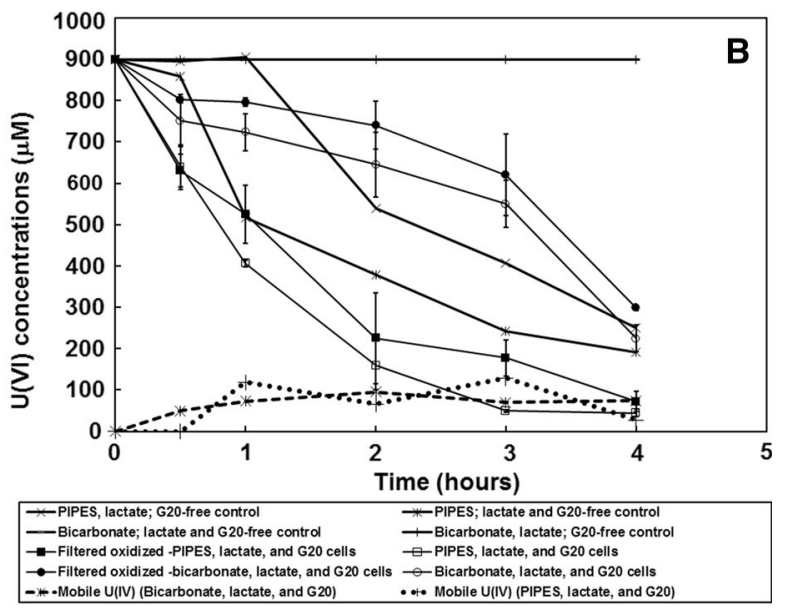

existing in mobile phase with the utilization of bicarbonate or PIPES buffer. Symbols show the mean of duplicate analyses. Error bars indicate the standard deviation 
filter reduced $U$ provides an indirect examination of the uraninite aggregates rather than the individual U(IV) particles, the approach followed here is deemed sufficient to allow the comparison of biogenic U(IV) particles produced under the different environmental conditions.

In the presence of PIPES buffer, an abiotic elimination of $\mathrm{U}$ at higher $(900 \mu \mathrm{M})$ concentration was also observed, where there was less abiotic removal at lower $(150 \mu \mathrm{M})$ concentration of $\mathrm{U}$. This indicated that PIPES buffer may have precipitated U abiotically as well, during the reduction by G20 in the case of $900 \mu \mathrm{M}$ initial $\mathrm{U}(\mathrm{VI})$ concentration, leading to the higher amount of $\mathrm{U}(\mathrm{VI})$ reduction compared to the bicarbonate buffered environment (Fig. 1). Thermodynamic speciation calculations using PHREEQC (Parkhurst and Appelo 1999) show that in the presence of PIPES buffer, schoepite solubility is reached. However, if this mineral is allowed to form, U(VI) concentrations sharply decrease, significantly deviating from the experimental data. The incorporation of a kinetically controlled schoepite precipitation might yield results consistent with the experiments, especially with the time-wise decrease in the abiotic U(VI) removal at $900 \mu \mathrm{M}$ initial $\mathrm{U}(\mathrm{VI})$ concentration as seen in Fig. 1b. However, such quantification is not considered here in order to minimize the risk of model over-parameterization. Thermodynamic speciation modeling showed that the dominant aqueous $\mathrm{U}(\mathrm{VI})$ species were $\left(\mathrm{UO}_{2}\right)_{3}(\mathrm{OH})_{5}^{+}$and $\left(\mathrm{UO}_{2}\right)_{5}(\mathrm{OH})_{7}^{+}$in addition to other uranyl hydroxo complexes such as $\mathrm{UO}_{2} \mathrm{OH}^{+}$and $\mathrm{UO}_{2}(\mathrm{OH})_{2}$, and uranyl lactate complexes. Sani et al. (2004) showed that there was no abiotic precipitation or reduction of $\mathrm{U}$ with $90 \mu \mathrm{M}$ initial U(VI) concentration in PIPES buffer. These observations were consistent with the results of Fredrickson et al. (2000), who showed that in $30 \mathrm{mM}$ PIPES buffer ( $\mathrm{pH} 7), 125 \mu \mathrm{M} \mathrm{U}(\mathrm{VI})$ remained in solution with a computed $\mathrm{U}(\mathrm{VI})$ aq equilibrium speciation that was dominated by the hydroxo complexes $\mathrm{UO}_{2} \mathrm{OH}_{(\mathrm{aq})}^{+}$or $\mathrm{UO}_{2}(\mathrm{OH})_{2(\mathrm{aq})}$. Slight decreases in $\mathrm{U}(\mathrm{VI})$ concentration were probably due to the adsorption of $\mathrm{U}(\mathrm{VI})$ onto the serum bottles (Arnold et al. 1988; Franklin et al. 2000). In contrast, there was no appearance of abiotic removal of $U$ in bicarbonate buffer at both concentrations of U(VI). An initial loss of $10 \%$ of the U(VI) was sometimes observed. This decrease in U(VI) may have been due to nonenzymatic interactions between the U(VI) and dead cell biomass of G20 cells (Payne et al. 2002). Thermodynamic speciation calculations in our study here also confirmed that the solubility of U(VI) solids such as schoepite was not reached in the presence of bicarbonate buffer. U(VI) speciation modeling showed that aqueous $\mathrm{U}(\mathrm{VI})$ was almost entirely complexed as $\mathrm{UO}_{2}\left(\mathrm{CO}_{3}\right)_{3}^{-4}$ around neutral $\mathrm{pH}$. Our planned future work includes the development of a numerical model to investigate the thermodynamic and kinetic constraints of the reaction network considered in the study based on the experimental results.

Comparison of biogenic U(IV) nanoparticles produced during growth versus non-growth conditions

Figure 2 shows the effects of growth conditions on the reduction of $150 \mu \mathrm{M}$ initial $\mathrm{U}(\mathrm{VI})$ by $\mathrm{G} 20$ in the presence of bicarbonate buffer. It is seen from Fig. 2 that the optical density (OD) measurements resulted in lower cell concentrations in the presence of $\mathrm{U}(\mathrm{VI})$, possibly due to the toxicity of U(VI) to the G20 cells. Interestingly, the results directly showed that even after 10 days of experimental period, the majority of the reduced $\mathrm{U}$ particles passed through the $0.2 \mu \mathrm{m}$ filter, presumably due to less aggregation of U(IV) in the aqueous phase. The mobile U(IV) concentration trend (dashed line in Fig. 2) calculated by the difference between filtered and filtered oxidized U(VI) concentration data indicates that the majority of the reduced $U$ remained in the aqueous phase (and thus being mobile), as opposed to the results obtained in non-growth conditions (Fig. 1).

The effect of growth versus non growth conditions on the aggregation of bioreduced $U$ particles in the aqueous phase was investigated in the presence of bicarbonate buffer because bicarbonate is a natural buffer commonly present at various $U$ contaminated sites (Bargar et al. 2008; Sani et al. 2006; White and Knowles 2000). The comparison of the transmission electron microscopy (TEM) images of D. Alaskensis G20 culture under non-growth (Fig. 3a-d) versus growth conditions (Fig. 3e, f) also confirmed the formation of higher amounts of reduced $\mathrm{U}$ aggregates under non-growth conditions, compared to less aggregation of reduced $\mathrm{U}$ particles under growth conditions, in accordance with the observations of filtered and filtered oxidized U(VI) concentrations as discussed 
Fig. 2 The growth of $D$. desulfuricans $\mathrm{G} 20$ and $150 \mu \mathrm{m} \mathrm{U}(\mathrm{VI})$ reduction under growth conditions in the presence of bicarbonate buffer (30 mM, pH 7) using sulfate as the electron acceptor and lactate as the electron donor. Symbols show the mean of duplicate analyses. Error bars indicate the standard deviation

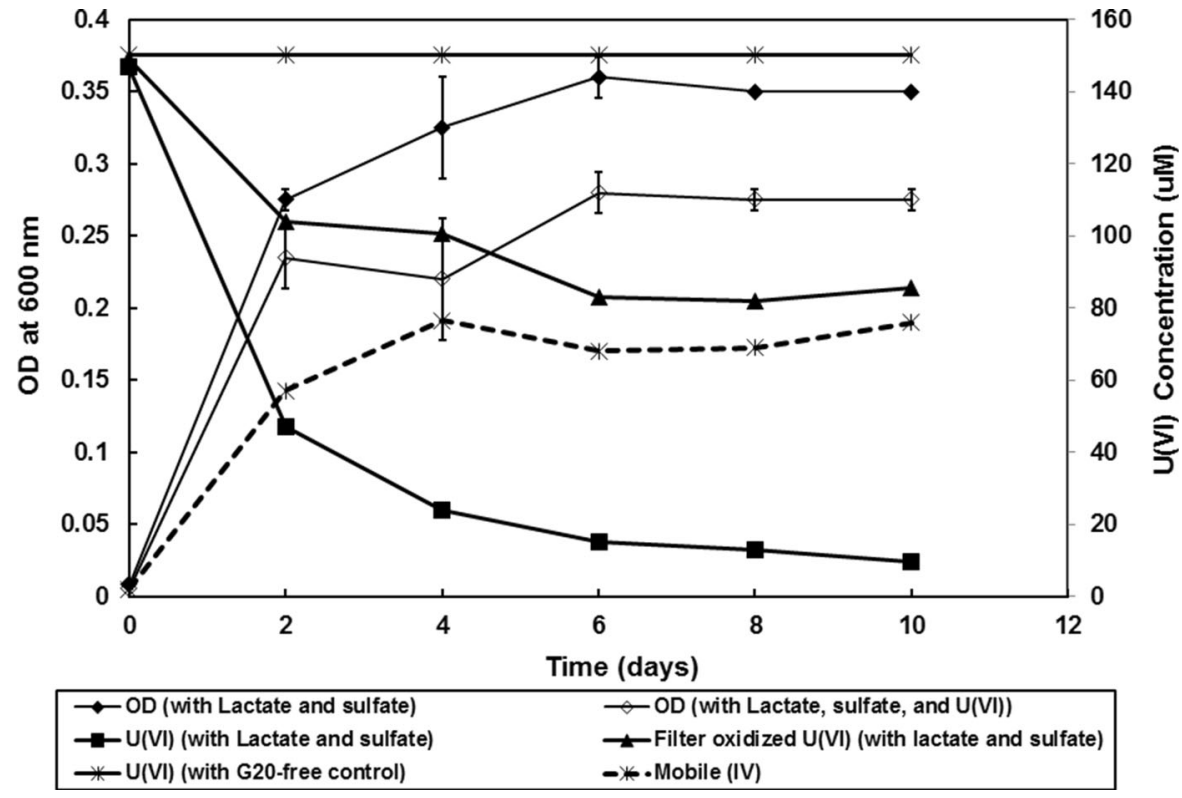

above. The results also showed that at higher $\mathrm{U}$ concentration $(900 \mu \mathrm{M})$, reduced $\mathrm{U}$ particles were more aggregated and did not passed through the filter compared to cases with lower U(VI) concentrations $(150 \mu \mathrm{M})$, as confirmed with the TEM images for $D$. Alaskensis G20 (Fig. 3). These images show that the reduced $\mathrm{U}$ particles are associated with the G20 cells (within the periplasm), and with higher $(900 \mu \mathrm{M})$ concentration of $\mathrm{U}$, the reduced $\mathrm{U}$ particles are observed to precipitate out as reduced $U$ crystals outside the cells. The differences observed in the aggregation of (IV) under growth versus non-growth conditions may be due to the different $\mathrm{U}(\mathrm{VI})$ reduction mechanisms (i.e., enzymatic and/or non-enzymatic reduction under growth conditions versus only enzymatic reduction under non-growth conditions). This may lead to the sites of $\mathrm{U}(\mathrm{VI})$ reduction or $\mathrm{U}(\mathrm{VI})$ reductase enzymes to be different in both conditions, including the possibility of sulfide abiotically reducing U(VI) under growth conditions. The reductive precipitation of U(VI) might have also been sensitive to the solution composition, where the complexation of the $\mathrm{U}$ with the growth medium components might possibly have enhanced the immobilization of U(IV), precluding its aggregation. Similar findings were also observed by Bernier-Latmani et al. (2010), who reported that the presence of various solutes in the water composition resulted in the inhibition of uraninite precipitation and the reduced $U$ products were observed to be associated with phosphates or carboxylate groups from the cell membrane. Also, in the present study, some of the $\mathrm{U}$ complexes which may not be able to enter the cell periplasm (e.g., U-schoepite complexes) might have had to be reduced outside the cell, resulting in the observed differences in aggregation under different conditions. In general, however, these U(VI) reduction mechanisms are not well understood and further research is needed.

The solubility of U(VI) was observed to be significantly lower in PIPES buffer than in bicarbonate buffer (Sani et al. 2006). Despite the lower solubility of U(VI) in PIPES buffer, less soluble U(VI) complexes in PIPES buffer exerted more toxicity to G20 compared to the highly soluble U(VI) carbonate complexes in the presence of bicarbonate buffer, as the uranium bicarbonate complexes \{almost entirely complexed as $\mathrm{UO}_{2}\left(\mathrm{CO}_{3}\right)_{2}^{-2}$ and $\left.\mathrm{UO}_{2}\left(\mathrm{CO}_{3}\right)_{3}^{-4}\right\}$ likely mitigated the toxicity effects of $U$ to G20. Previous reports on U(VI) toxicity to G20 in the presence of PIPES buffer under growth conditions was demonstrated by longer lag times and in some cases by no measurable growth for U(VI) concentrations of $\geq 175 \mu \mathrm{M}$ (Sani et al. 2006). The importance of the choice of buffer was also studied by White and Knowles (2000), where the use of PIPES buffer prevented the degradation of nitrilotriacetic acid by Chelatobacter heintzii. Analysis of thin sections of G20 treated with $900 \mu \mathrm{M}$ U(VI) in medium containing 


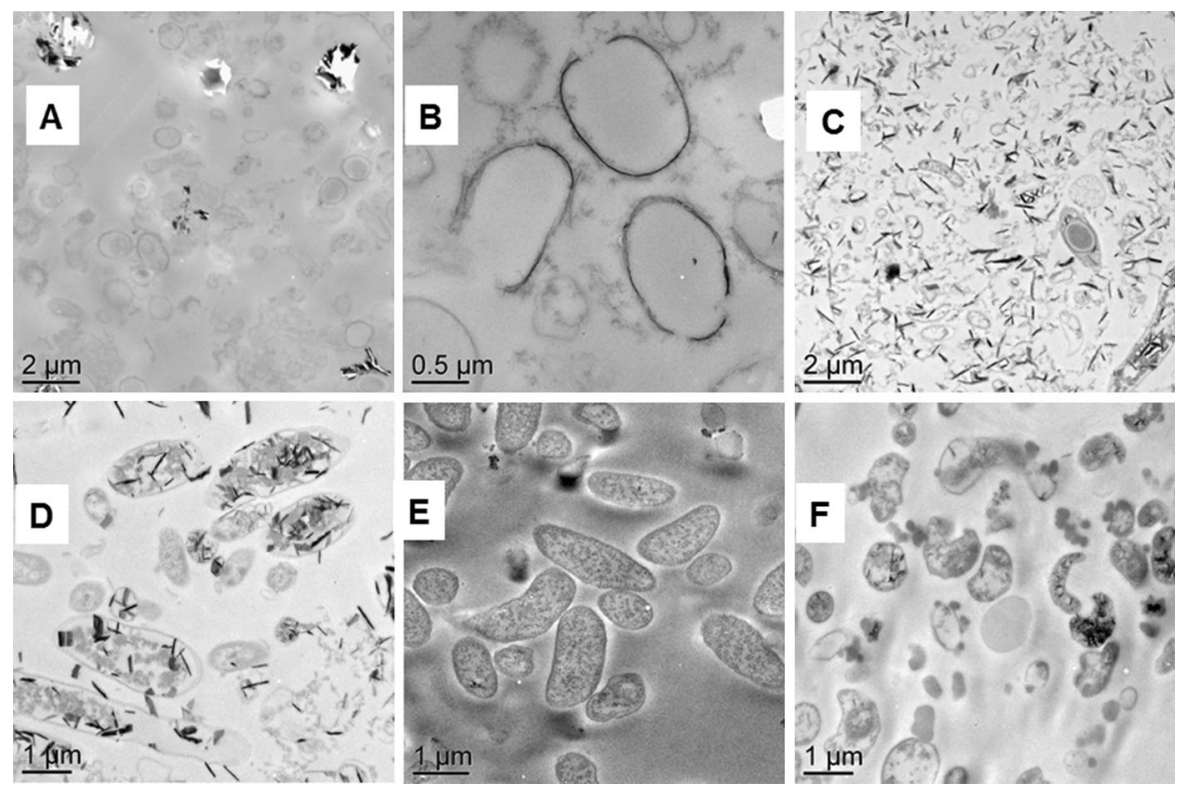

Fig. 3 Transmission electron microscopic images of Desulfovibrio desulfuricans G20 culture treated with a and b $150 \mu \mathrm{m}$ U(VI) under non-growth, c and d $900 \mu \mathrm{m}$ U(VI) under non-

PIPES buffer revealed that only a very small fraction of cells had reduced $U$ precipitates in the periplasmic spaces. In the presence of bicarbonate buffer, however, reduced $U$ was observed not only in the periplasm but also in the cytoplasm. These nongrowth conditions results corroborated with the previous studies by Sani et al. (2006).

The minimum aggregation of biogenic U(IV) at lower concentration of $U$ was not well understood although cell density of G20 was the same in all experiments. It is generally believed that uraninite aggregates near the site of U(VI) reduction. For most Gram-negative bacteria, biogenic uraninite is localized in the periplasmic space and outside of the cells suggesting the presence of $U$ reductases composed of electron-carrier proteins or enzymes within the periplasm, on the outer membrane or outside of the cytoplasmic membrane (Wall and Krumholz 2006). Further, study of the relative localization of uraninite nanoparticles and c-type cytochromes showed their close extracellular association in a matrix of exopolymeric substances (EPS) (Marshall et al. 2006). A separate study demonstrated the strong binding of a cytochrome c3 to uraninite (Payne et al. 2004). These studies support the hypothesis that aggregation occurs near the site of reduction. Despite its small size, the growth, e $150 \mu \mathrm{m} \mathrm{U}(\mathrm{VI})$ under growth, and f $900 \mu \mathrm{m} \mathrm{U}(\mathrm{VI})$ under growth conditions in medium containing bicarbonate buffer (30 mM, pH 7)

association of biogenic U(IV) with proteins and EPS, associated with the biomass, makes its unlikely to be transported as colloidal phases (Bargar et al. 2008). However, after U bioreduction, Fe(III)hydroxide minerals as well as Fe sulfide minerals, reduced organic matter, electron shuttles could be controlling factors for the transport and long-term stability of bioreduced U (Singh et al. 2014). Wang et al. (2013) report mobile U(IV)-bearing colloids in a mining-impacted wetland demonstrating the presence of U(IV) in soil as a noncrystalline species bound to amorphous Al-P-Fe-Si aggregates, whereas in porewater, as a distinct species associated with Fe and organic matter colloids. Therefore, further research is needed to quantify the mobile and immobile fractions of the reduced $U$ nanoparticles, develop reactive transport models to understand and predict the mobility of $U$ nanoparticulate phases under relevant field conditions where both biotic and abiotic pathways occur for $\mathrm{U}$ reduction.

$\mathrm{U}(\mathrm{VI})$ reduction under growth conditions and effects of different electron acceptors and donors on the bioreduced $U$ aggregation

In order to help in the selection of the right electron donor for $\mathrm{U}$ bioremediation in the field, the effects of 
three different electron acceptors (sulfate, thiosulfate or fumarate) and two donors (lactate or pyruvate) were studied on the aggregation of bioreduced U nanoparticles in the aqueous phase under growth conditions of G20 in MTM (Figs. 4 through 6). The OD versus time plots as well as $\mathrm{U}(\mathrm{VI})$ trends versus time for $\mathrm{U}(\mathrm{VI})$ bioreduction by $\mathrm{G} 20$ under growth conditions with the electron acceptors of fumarate and thiosulfate, are shown in Fig. 4a, b respectively, with the utilization of lactate as the electron donor. The filtered and filtered oxidized U(VI) concentration trends show that under growth conditions, significant mass fraction of bioreduced $\mathrm{U}$ existed as a mobile (particulate) phase when the initial $\mathrm{U}(\mathrm{VI})$ was $150 \mu \mathrm{M}$ (see dashed lines in Fig. 4). When thiosulfate was utilized as the electron acceptor compared to fumarate, lower amount of mobile U(IV) fraction was observed, which was due to the lower amount of U(VI) bioreduction $(70 \%)$ that occurred with thiosulfate compared to the other electron acceptors (Fig. 6). When a different electron donor, i.e., pyruvate was used instead of lactate with the electron acceptors sulfate, fumarate and thiosulfate, still significant fraction of bioreduced $\mathrm{U}$ (30-60\%) was observed to be in the mobile phase (see dashed lines in Fig. 5a-c). Again, the lowest amount of mobile U(IV) fraction corresponded to the utilization of thiosulfate which was due to the lowest amount of U(VI) bioreduction with thiosulfate. In general, the OD measurements for G20 cells in the presence of U(VI) showed slightly lower values compared to the growth conditions in the absence of $\mathrm{U}(\mathrm{VI})$, possibly due to the toxicity of U(VI) to the cells under all conditions. Also, when fumarate was used as the electron acceptor either with pyruvate or lactate as the electron donor, lowest OD measurements were observed for the G20 cells (see Figs. 4a, 5b) compared with the growth conditions using sulfate or thiosulfate. The actual U(VI) bioreduction mechanisms with these electron acceptors are not well understood and further research is needed to explain the observed differences.

Figure 6 shows the \% U reduction obtained and the $\%$ of filtered reduced $U$ (i.e., existing in the mobile phase) for all the different electron acceptor and donors considered here under growth conditions. It is also seen from this bar chart that although greater than $90 \%$ of U(VI) reduction was accomplished with the utilization of sulfate or fumarate as the electron acceptor and lactate or pyruvate as the electron donor, greater than $50 \%$ of the filtered reduced $\mathrm{U}$ still existed in mobile phase, thus posing challenges regarding the potential fate and transport of the bioreduced $U$ particles as (or associated with other) colloidal phases, and hence towards long-term $U$ reclamation stewardship. The use of thiosulfate as an electron acceptor yielded smallest proportion of U(VI) reduction (68\%) in 10 days of incubation compared to the case when sulfate or fumarate were used but still greater than $25 \%$ of the filtered reduced $\mathrm{U}$ existed in mobile phase (Fig. 6). The mechanisms of aggregation of bioreduced $\mathrm{U}$ with the tested electron donors and acceptors are not well understood. For the majority of contaminated sites, competing electron acceptors in addition to $\mathrm{U}(\mathrm{VI})$, could either enhance or inhibit $\mathrm{U}(\mathrm{VI})$ reduction.

\section{Evaluation of size fractionation of biogenic U(IV) nanoparticles}

A size fractionation experiment was performed on the bioreduced $U$ nanoparticle precipitates that were formed as a result of U(VI) bioreduction by G20 cells under growth conditions in the presence of lactate, sulfate, and bicarbonate buffer (30 mM, pH 7). Biogenic reduced $U$ which passed through the $0.2 \mu \mathrm{m}, 3,10$ or $30 \mathrm{kD}$ cut-off membrane filters were analyzed to obtain the size of the reduced $U$ particles as shown in Fig. 7 (see solid bars of filtered reduced U $\%$ for various filter sizes). The comparison shows a significant size difference in the particles from oxidized samples filtered at $0.2 \mu \mathrm{m}$ and nano-filtered samples. The results show that about $65 \%$ of the reduced $U$ could pass through the $0.2 \mu \mathrm{m}$ filter, whereas, only 10,4 and $2 \%$ of the reduced $U$ could pass through the 30 (pore size of $18 \mathrm{~nm}$ ), 10 (pore size of $6 \mathrm{~nm}$ ) and 3 (pore size of $1.8 \mathrm{~nm}$ ) filters, respectively. This indicates that the bioreduced $U$ particles occurred in sizes greater than $18 \mathrm{~nm}$ (not passing through $30 \mathrm{kD}$ filter), but they were less than $200 \mathrm{~nm}$ (passing through $0.2 \mu \mathrm{m}$ filter), and hence considered to be mobile. However, it should be noted that this fractionation analysis showed the size range of U(IV) particle aggregates, where the actual bioreduced $\mathrm{U}$ particles can be smaller than the aggregates retained by the previously collected particles on the filter membrane. Previous studies on the biogenic uraninite produced by $D$. alaskensis G20, Shewanella sp. HRCR-2, A. dehalogenans, G. sulfurreducens, and D. vulgaris were reported to have sizes in the range of 


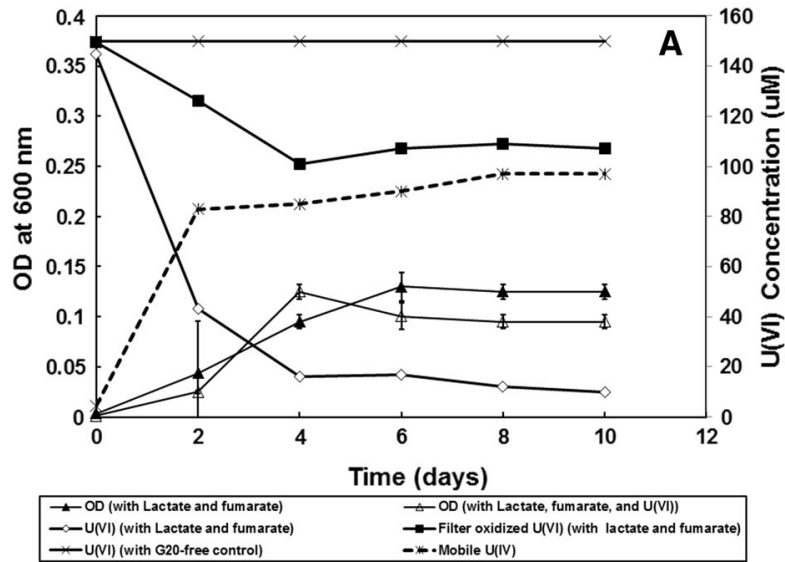

Fig. 4 The effects of two different electron acceptors a fumarate, $\mathbf{b}$ thiosulfate on the growth of $D$. desulfuricans $\mathrm{G} 20$ and $150 \mu \mathrm{mU}(\mathrm{VI})$ reduction under growth conditions in the presence of bicarbonate buffer $(30 \mathrm{mM}, \mathrm{pH} 7)$ and in the

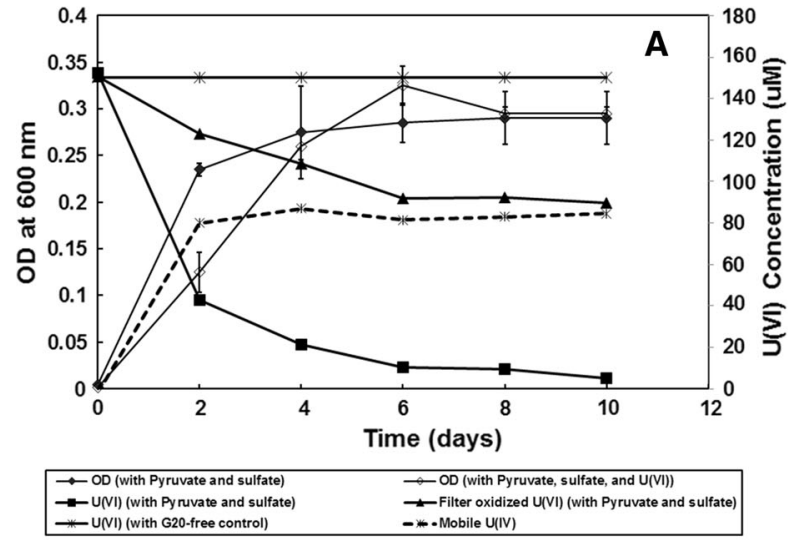

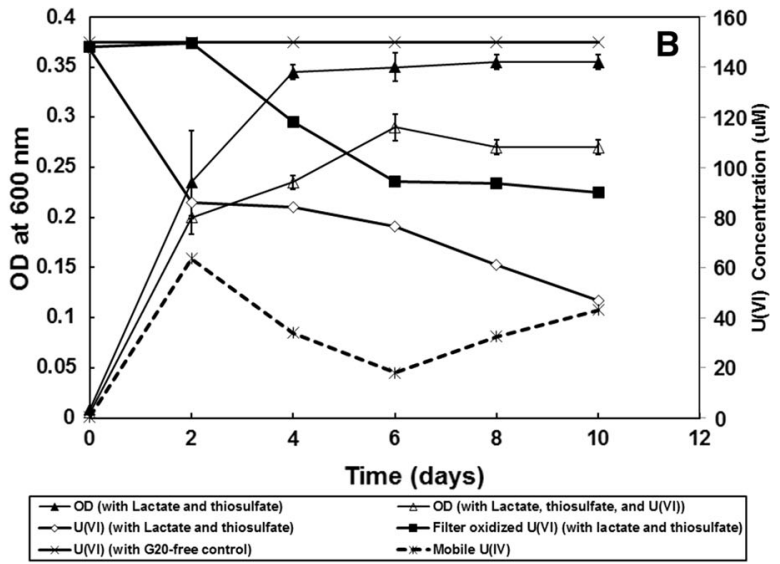

presence of lactate as the electron donor. Symbols show the mean of duplicate analyses. Error bars indicate the standard deviation

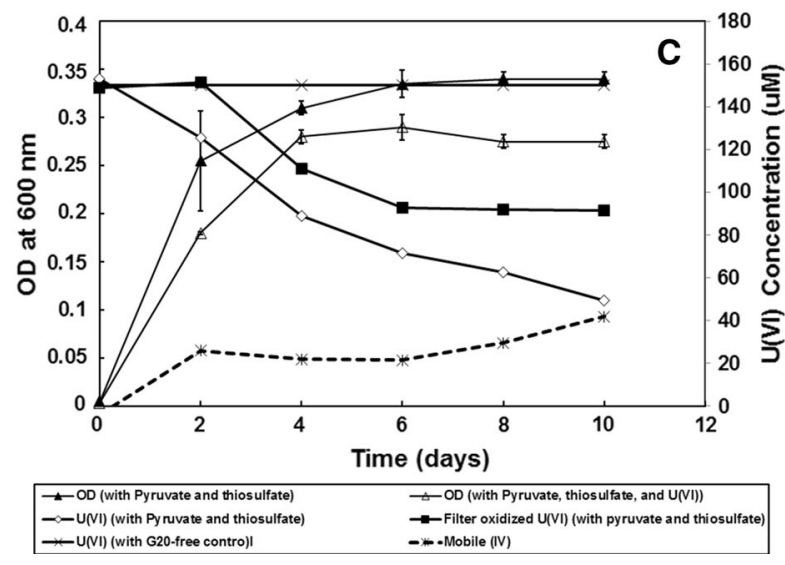

Fig. 5 The effects of 3 different electron acceptors a sulfate, b fumarate, $\mathbf{c}$ thiosulfate on the growth of $D$. desulfuricans $\mathrm{G} 20$ and $150 \mu \mathrm{mU}(\mathrm{VI})$ reduction under growth conditions in the presence of bicarbonate buffer $(30 \mathrm{mM}, \mathrm{pH} 7)$ and in the presence of pyruvate as the electron donor. Symbols show the mean of duplicate analyses. Error bars indicate the standard deviation 
Fig. 6 Comparative distribution of $\% \mathrm{U}(\mathrm{VI})$ reduction and $\%$ filtered reduced $U$ existing in mobile phase with the utilization of three different electron acceptors (sulfate, fumarate, thiosulfate) and two different electron donors (lactate, pyruvate) by the growth of $D$. desulfuricans G20 with $150 \mu \mathrm{m}$ initial U(VI) under growth conditions in the presence of bicarbonate buffer $(30 \mathrm{mM}$, $\mathrm{pH}$ 7). Error bars indicate the standard deviation

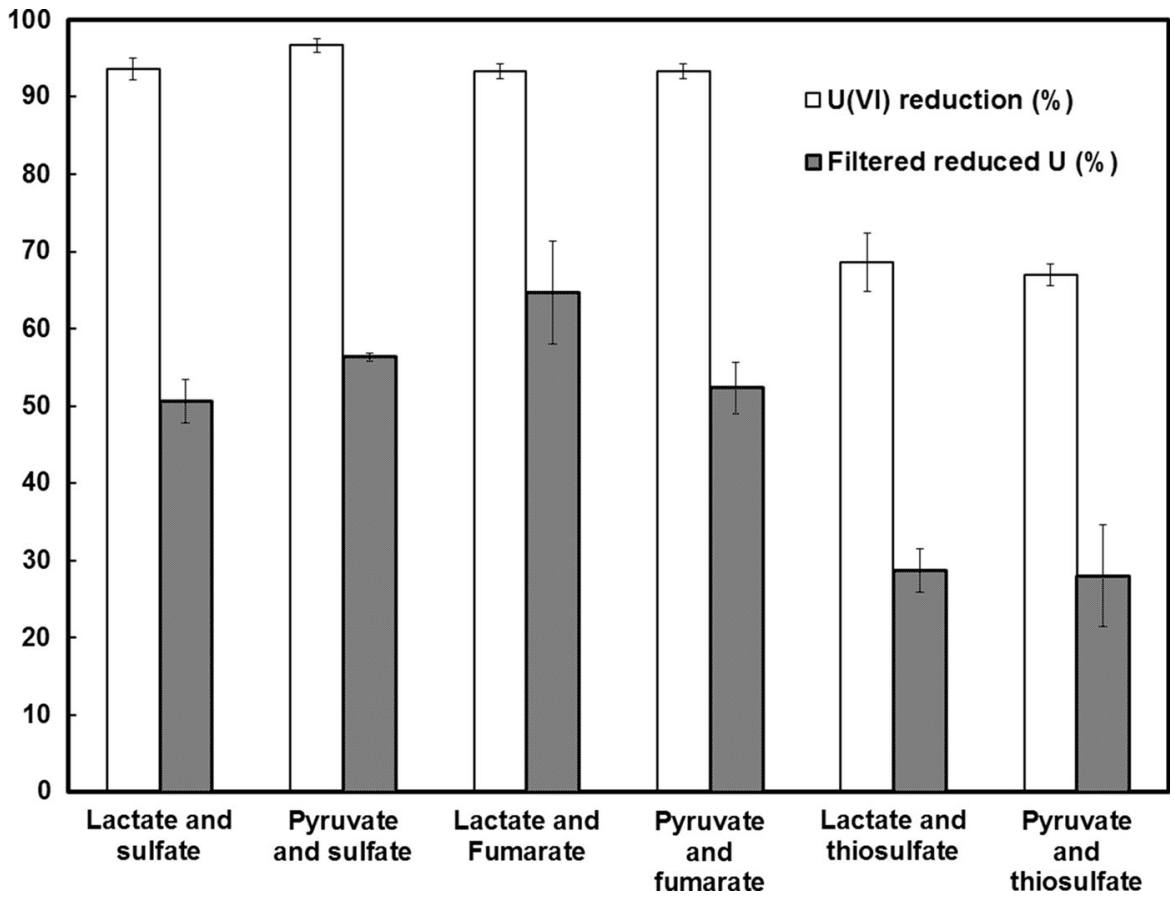

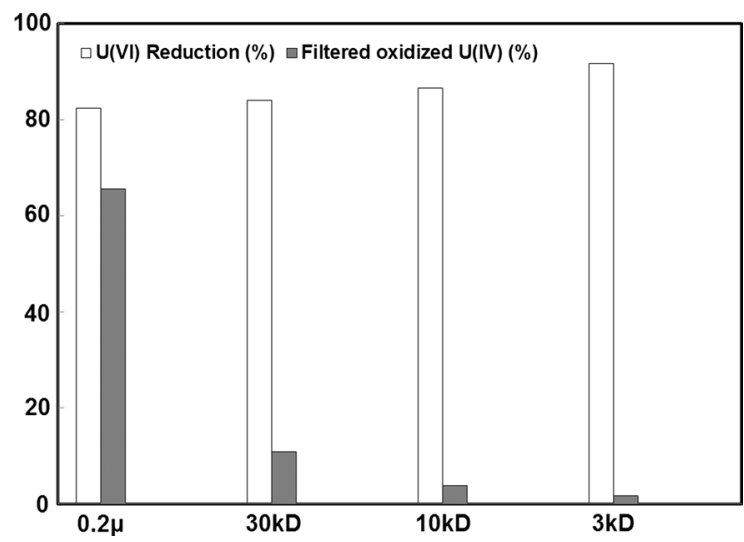

Fig. 7 Comparative distribution of \% U(VI) reduction and \% filtered reduced $U$ showing size fractionation of the biogenic reduced $U$ which passed through the $0.2 \mu \mathrm{m}, 3,10$ and $30 \mathrm{kD}$ membrane filters, under growth conditions of $D$. desulfuricans $\mathrm{G} 20$ in the presence of bicarbonate buffer $(30 \mathrm{mM}, \mathrm{pH}$ 7)

1.5-5 nm (Schofield et al. 2008; Sharpe et al. 2009; Sani et al. 2006; Zhou et al. 2014a) for the individual particles. The difference in the observed sizes in this study could be due to aggregation or complexation of the reduced $U$ with the growth medium components, thus yielding bulk sizes greater than $18 \mathrm{~nm}$. Biogenic reduced $U$ nanoparticles in aggregates of up to $30 \mathrm{~nm}$ in diameter at slow rates of $\mathrm{U}(\mathrm{VI})$ bioreduction, and aggregates of up to $100 \mathrm{~nm}$ in $\mathrm{U}$ contaminated groundwater samples have also been observed by Senko et al. (2007), and Abdelouas et al. (1999), respectively. As discussed by Senko et al. (2007), in addition to the changes in reactive surface area, structural changes in biogenic reduced $U$ particles might also be induced upon aggregation changing their reactivity, compared to the non-aggregated individual reduced $\mathrm{U}$ particles.

\section{Conclusions}

This study provides important insights on the impact of different environmental conditions on the mobility of bioreduced U, which would have significant influence on the ultimate success of uranium bioremediation efforts in the field. The present study is a first attempt to explore the complex interaction of multiple electron acceptors (sulfate, thiosulfate, or fumarate) and donors (lactate or pyruvate) during U(VI) reduction and immobilization by $D$. alaskensis G20. Furthermore, the effect of the two buffers (bicarbonate or PIPES) and the behavior of G20 under growth versus non-growth conditions on the aggregation of the bioreduced $\mathrm{U}$ nanoparticles are 
also presented. The results show that the aggregation of the U(IV) nanoparticles highly depend on the initial concentration of U(VI), and the type of buffer, electron acceptors and donors utilized in the environment. The study demonstrates that although more than $90 \%$ of U(VI) reduction could be accomplished with the utilization of various different electron donors and acceptors, a significant mass fraction of bioreduced U (28-65\%) still exists as a mobile nanoparticulate phase under growth conditions. Our results show that under non-growth conditions, the majority of the reduced $U$ occurs in the form of reduced $U$ aggregates that are able to precipitate out from the solution, as opposed to a mobile form of U(IV) obtained under growth conditions. Such differences may be due to the different $U(V I)$ reduction mechanisms as well as the impact of U complexation with the growth medium components under the different conditions. Our size fractionation results of the reduced $\mathrm{U}$ nanoparticles also show that most of the bioreduced $\mathrm{U}$ aggregates were in sizes between $18 \mathrm{~nm}$ and $0.2 \mu \mathrm{m}$ and should be considered to be mobile. These observations have fundamental relevance to the conditions existing in the natural subsurface environments that are contaminated with $\mathrm{U}$, and would pose significant challenges to the ongoing bioremediation efforts to remove U(VI) by reductive precipitation by microorganisms. For the successful application of biostimulation of uranium, it is vital to understand the governing factors that control the behavior of these extracellular bioreduced $\mathrm{U}$ species with respect to $\mathrm{U}$ fate, transport, and long term stability. This study provides insights on the size and potential mobility of reduced $U$ nanoparticles and their potential impact on U(VI) bioremediation at contaminated sites where sulfate reducing conditions have been shown to develop under natural and biostimulated environments. Further fundamental research is needed to quantify the mobile and immobile fractions of the reduced $U$ nanoparticles and develop numerical biogeochemical models to predict the colloidal phase transport and long-term stability of bioreduced $\mathrm{U}$.

Acknowledgments The authors acknowledge the financial support provided by Environmental Remediation Sciences Program (ERSP) within the office of Biological and Environmental Research, U.S. Department of Energy (grant\# DE-FG02-07-ER-64366 with Subaward\#G125-08-W1577). A portion of the research was performed using EMSL, a national scientific user facility sponsored by the Department of Energy's Office of Biological and Environmental Research and located at Pacific Northwest National Laboratory. Rajesh Sani also acknowledges the support from the Department of Chemical and Biological Engineering at the South Dakota School of Mines and Technology.

\section{References}

Abdelouas A, Lutze W, Nuttall HE (1999) Oxidative dissolution of uraninite precipitated on Navajo sandstone. J Contam Hydrol 36:353-375

Anderson RT, Vrionis HA, Ortiz-Bernad I, Resch CT, Long PE, Dayvault R, Karp K, Marutzky S, Metzler DR, Peacock A, White DC, Lowe M, Lovley DR (2003) Stimulating the in situ activity of Geobacter species to remove uranium from the groundwater of a uranium-contaminated aquifer. Appl Environ Microbiol 69:5884-5891

Arnold RG, DeChristina TJ, Hoffman MR (1988) Reductive dissolution of $\mathrm{Fe}(\mathrm{III})$ oxides by Pseudomonas sp. 200. Biotechnol Bioengineer 32:1081-1096

Bargar JR, Bernier-Latmani R, Giammar DE, Tebo BM (2008) Biogenic uraninite nanoparticles and their importance for uranium remediation. Elements 4(6):407-412

Bernier-Latmani R, Veeramani H, Della Vecchia E, Junier P, Lezama-Pacheco JS, Suvorova EI, Sharp JO, Wigginton NS, Bargar JR (2010) Non-uraninite products of microbial U(VI) reduction. Environ Sci Technol 44:9456-9462

Bethke CM, Sanford RA, Kirk MF, Jin Q, Flynn TM (2011) The thermodynamic ladder in geomicrobiology. Am J Sci 311(3):183-210

Beyenal H, Sani RK, Peyton BM, Dohnalkova A, Amonette JE, Lewandowski Z (2004) Uranium immobilization by sulfate reducing biofilms. Environ Sci Technol 38:2067-2074

Boyanov MI, Fletcher KE, Kwon MJ, Rui X, O’Loughlin EJ, Löffler FE, Kemner KM (2011) Solution and microbial controls on the formation of reduced U(IV) species. Environ Sci Technol 45:8336-8344

Burgos WD, McDonough JT, Senko JM, Zhang G, Dohnalkova AC, Kelly SD, Kemner KM (2008) Characterization of uraninite nanoparticles produced by Shewanella oneidensis MR-1. Geochim Cosmochim Acta 72(20):4901-4915

Converse BJ, Wu T, Findlay RH, Roden EE (2013) U (VI) reduction in sulfate-reducing subsurface sediments amended with ethanol or acetate. Appl Environ Microbiol 79(13):4173-4177

Elias DA, Suflita JM, McInerney MJ, Krumholz LR (2004) Periplasmic cytochrome c3 of Desulfovibrio vulgaris is directly involved in H2-mediated metal but not sulfate reduction. Appl Environ Microbiol 70:413-420

Esteve-Núnez A, Núnez C, Lovley DR (2004) Preferential reduction of $\mathrm{Fe}(\mathrm{III})$ over fumarate by Geobacter sulfurreducens. J Bacteriol 186(9):2897-2899

Finneran KT, Housewright ME, Lovley DR (2002) Multiple influences of nitrate on uranium solubility during bioremediation of uranium-contaminated subsurface sediments. Environ Microbiol 4:510-516

Fletcher KE, Boyanov MI, Thomas SH, Wu Q, Kemner KM, Löffler FE (2010) U(VI) reduction to mononuclear U(IV) 
by Desulfitobacterium species. Environ Sci Technol 44(12):4705-4709

Franklin NM, Stauber JL, Markich SJ, Lim RP (2000) pHDependent toxicity of copper and uranium to a tropical freshwater alga (Chlorella sp.). Aquat Toxicol 48:275-289

Fredrickson JK, Zachara JM, Kennedy DW, Duff MC, Gorby YA, Li SW, Krupka KM (2000) Reduction of U(VI) in goethite (a-FeOOH) suspensions by a dissimilatory metal reducing bacterium. Geochim Cosmochim Acta 64:30853098

Fredrickson JK, Zachara JM, Kennedy DW, Liu C, Duff MC, Hunter DB, Dohnalkova A (2002) Influence of Mn oxides on the reduction of uranium(VI) by the metal-reducing bacterium Shewanella putrefaciens. Geochim Cosmochim Acta 66:3247-3262

Ganesh R, Robinson KG, Reed GD, Sayler G (1997) Reduction of hexavalent uranium from organic complexes by sulfateand iron-reducing bacteria. Appl Environ Microbiol 63:4385-4391

Gorby YA, Lovley DR (1992) Enzymatic uranium precipitation. Environ Sci Technol 16:205-207

Hauser LJ, Land ML, Brown SD, Larimer F, Keller KL, RappGiles BJ, Price MN, Lin M, Bruce DC, Detter JC, Tapia R (2011) Complete genome sequence and updated annotation of Desulfovibrio alaskensis G20. J Bacteriol 193(16): 4268-4269

Holmes DE, Finneran KT, Lovley DR (2002) Enrichment of Geobacteraceae associated with stimulation of dissimilatory metal reduction in uranium-contaminated aquifer sediments. Appl Environ Microbiol 68:2300-2306

Istok JD, Senko JM, Krumholz LR, Watson D, Bogle MA, Peacok A, Chang Y-J, White DC (2004) In situ bioreduction of technitium uranium in a nitrate-contaminated aquifer. Environ Sci Technol 38:468-475

Junier P, Suvorova EI, Bernier-Latmani R (2010) Effect of competing electron acceptors on the reduction of $\mathrm{U}(\mathrm{VI})$ by Desulfotomaculum reducens. Geomicrobiol J 27(5):435443

Liu CX, Gorby YA, Zachara JM, Fredrickson JK, Brown CF (2002) Reduction kinetics of Fe(III), Co(III), U(VI) Cr(VI) and $\mathrm{Tc}(\mathrm{VII})$ in cultures of dissimilatory metal-reducing bacteria. Biotech Bioeng 80:637-649

Lovley DR (1991) Dissimilatory Fe and Mn reduction. Micobiol Rev 55:259-287

Lovley DR, Phillips EJP (1992) Bioremediation of uranium contamination with enzymatic uranium reduction. Environ Sci Technol 26:2228-2234

Luo WS, Wu WM, Yan TF, Criddle CS, Jardine PM, Zhou JZ, $\mathrm{Gu} \mathrm{BH}$ (2007) Influence of bicarbonate, sulfate, and electron donors on biological reduction of uraniumand microbial community composition. Appl Microbiol Biotechnol 77(3):713-721

Maleke M, Williams P, Castillo J, Botes E, Ojo A, DeFlaun M, van Heerden E (2015) Optimization of a bioremediation system of soluble uranium based on the biostimulation of an indigenous bacterial community. Environ Sci Pollut Res Intl 22(11):8442-8450

Marshall MJ et al (2006) c-type cytochrome-dependent formation of U(IV) nanoparticles by Shewanella oneidensis. PLoS Biol 4:1324-1333
Marshall MJ, Dohnalkova AC, Kennedy DW, Plymale AE, Thomas SH, Loffler FE, Sanford RA, Zachara JM, Fredrickson JK, Beliaev AS (2009) Electron donor-dependent radionuclide reduction and nanoparticle formation by Anaeromyxobacter dehalogenans strain 2CP-C. Environ Microbiol 11(2):534-543

Moon HS, Komlos J, Jaffé PR (2009) Biogenic U(IV) oxidation by dissolved oxygen and nitrate in sediment after prolonged $\mathrm{U}(\mathrm{VI}) / \mathrm{Fe}(\mathrm{III}) / \mathrm{SO}(4)(2-)$ reduction. J Contam Hydrol 105:18-27

Nealson KH, Saffarini D (1994) Iron and manganese in anaerobic respiration: environmental significance, physiology, and regulation. Annu Rev Microbiol 48:311-343

Nevin KP, Finneran KT, Lovley DR (2003) Microorganisms associated with uranium bioremediation in a high-salinity subsurface sediment. Appl Environ Microbiol 69(6):36723675

Parkhurst DL, Appelo CAJ (1999) User's guide to PHREEQC (version 2) - a computer program for speciation, batchreaction, onedimensional transport, and inverse geochemical calculations. US Department of Transport modeling Batch-reaction and transport calculations, Denver

Payne RB, Gentry DM, Rapp-Giles BJ, Casalot L, Wall JD (2002) Uranium reduction by Desulfovibrio desulfuricans strain G20 and a cytochrome c3 mutant. Appl Environ Microbiol 68(6):3129-3132

Payne RB, Casalot L, Rivere T, Terry JH, Larsen L, Giles BJ, Wall JD (2004) Interaction between uranium and the cytochrome c(3) of Desulfovibrio desulfuricans strain G20. Archives Microbiol 181:398-406

Pietzsch K, Babel W (2003) A sulfate-reducing bacterium that can detoxify $\mathrm{U}(\mathrm{VI})$ and obtain energy via nitrate reduction. J Basic Microbiol 43:348-361

Prakash O, Gihring TM, Dalton DD, Chin KJ, Green SJ, Akob DM, Kostka JE (2010) Geobacter daltonii sp. nov., an $\mathrm{Fe}$ (III)-and uranium (VI)-reducing bacterium isolated from a shallow subsurface exposed to mixed heavy metal and hydrocarbon contamination. Intl J Syst Evol Microbiol 60(3):546-553

Sani RK, Geesey G, Peyton BM (2001) Assessment of Pb toxicity to Desulfovibrio desulfuricans G20: influence of components of lactate C medium. Adv Environ Res 5(3):269-276

Sani RK, Peyton BM, Amonette JE, Geesey GG (2004) Reduction of uranium(VI) under sulfate reducing conditions in the presence of $\mathrm{Fe}(\mathrm{III})$-(hydr)oxides. Geochim Cosmochim Acta 68:2639-2648

Sani RK, Peyton BM, Dohnalkova A (2006) Effect of uranium(VI) in aqueous media on Desulfovibrio desulfuricans G20. Environ Toxico Chem 25:1231-1238

Sani RK, Peyton BM, Dohnalkova A (2008) Comparison of uranium(VI) removal by Shewanella oneidensis MR-1 in flow and batch reactors. Water Res 42(12):2993-3002

Schofield EJ, Veeramani H, Sharp JO, Suvorova E, BernierLatmani R, Mehta A, Stahlman J, Clark DL, Conradson SD, Ilton ES, Bargar JR (2008) Structure of biogenic uraninite produced by Shewanella oneidensis strain MR-1. Environ Sci Technol 42(21):7898-7904

Senko JM, Kelly SD, Dohnalkova AC, McDonough JT, Kemner KM, Burgos WD (2007) The effect of U (VI) bioreduction 
kinetics on subsequent reoxidation of biogenic U (IV). Geochim Cosmochim Acta 71(19):4644-4654

Sharpe JO, Schofield EL, Veeramani H, Suvorova EI, Kennedy DW, Marshall MJ, Metha A, Bargar JR, Bernier-Latmani R (2009) Structural similarities between biogenic uraninites produced by phylogenetically and metabolically diverse bacteria. Environ Sci Technol 43:8295-8301

Shelobolina ES, Vrionis HA, Findlay RH, Lovley DR (2008) Geobacter uraniireducens sp. nov., isolated from subsurface sediment undergoing uranium bioremediation. Intl $\mathrm{J}$ Syst Evol Microbiol 58(5):1075-1078

Singh G, Şengör SS, De J, Bhalla A, Kumar S, Stewart B, Squillace E, Spycher N, Ginn T, Peyton B, Sani RK (2014) Reoxidation of biogenic reduced uranium-a challenge towards bioremediation. Crit Rev Environ Sci Technol 44:391-415

Spear JR, Figueroa LA, Honeyman BD (1999) Modeling the removal of uranium $\mathrm{U}(\mathrm{VI})$ from aqueous solutions in the presence of sulfate reducing bacteria. Environ Sci Technol 33:2667-2675

Spycher NF, Issarangkun M, Stewart B, Sengor S, Belding E, Ginn TM, Peyton BM, Sani RK (2011) On modeling biogenic uraninite precipitation and reoxidation by Iron(III)(hydr)oxides: thermodynamic and kinetic considerations. Geochim Cosmochim Acta 75:4426-4440

Stylo M, Neubert N, Roebbert Y, Weyer S, Bernier-Latmani R (2015) Mechanism of uranium reduction and immobilization in Desulfovibrio vulgaris biofilms. Environ Sci Technol 49(17):10553-10561

Suzuki Y, Suko T (2006) Geomicrobiological factors that control uranium mobility in the environment: update on recent advances in the bioremediation of uranium-contaminated sites. J Mineral Pet Sci 101(6):299-307

Suzuki Y, Kemner KM, Banfield JF (2002) Nanometre-size products of uranium bioreduction. Nature 419:134

Tapia-Rodriguez A, Luna-Velasco A, Field JA, Sierra-Alvarez R (2010) Anaerobic bioremediation of hexavalent uranium in groundwater by reductive precipitation with methanogenic granular sludge. Water Res 44(7):2153-2162
Vrionis HA, Anderson RT, Ortiz-Bernad I, O’Neill KR, Resch CT, Peacock AD, Dayvault R, White DC, Long PE, Lovley DR (2005) Microbiological and geochemical heterogeneity in an in situ uranium bioremediation field site. Appl Environ Microbiol 71:6308-6318

Wall JD, Krumholz LR (2006) Uranium reduction. Annu Rev Microbiol 60:149-166

Wang Y, Frutschi M, Suvorova E, Phrommavanh V, Descostes M, Osman AA, Geipeg G, Bernier-Latmani R (2013) Mobile uranium(IV)-bearing colloids in a mining-impacted wetland. Nat commun 4:2942. doi: $10.1038 /$ ncomms3942

White VE, Knowles CJ (2000) Effect of metal complexation on the bioavailability of nitrilotriacetic acid to Chelatobacter heintzii ATCC 29600. Archives Microbiol 173(5-6):373382

Williams KH, Long PE, Davis JA, Wilkins MJ, N'guessan AL, Steefel CI, Yang L, Newcomer D, Kerkhof LJ, Mcguinness L, Dayvault R, Lovley DR (2011) Acetate availability and its influence on sustainable bioremediation of uraniumcontaminated groundwater. Geomicrobiol J 28:519-539

Wu Q, Sanford RA, Löffler FE (2006) Uranium (VI) reduction by Anaeromyxobacter dehalogenans strain 2CP-C. Appl Environ Microbiol 72(5):3608-3614

Wu WM, Carley J, Luo J, Ginder-VogelMA Cardenas E, LeighMB Hwang CC, Kelly SD, Ruan CM, Wu LY, Van Nostrand J, Gentry T, Lowe K, Mehlhorn T, Carroll S, LuoWS FieldsMW, Gu BH, Watson D, Kemner KM, Marsh T, Tiedje J, Zhou JZ, Fendorf S, Kitanidis PK, Jardine PM, Criddle CS (2007) In situ bioreduction of uranium (VI) to submicromolar levels and reoxidation by dissolved oxygen. Environ Sci Technol 41:5716-5723

Zhou C, Vannela R, Hyun SP, Hayes KF, Rittmann BE (2014a) Growth of Desulfovibrio vulgaris when respiring U (VI) and characterization of biogenic uraninite. Environ sci tech 48(12):6928-6937

Zhou C, Ontiveros-Valencia A, de Saint Cornette, Cyr L, Zevin AS, Carey SE, Krajmalnik-Brown R, Rittmann BE (2014b) Uranium removal and microbial community in a H2-based membrane biofilm reactor. Water Res 64:255-264 